\title{
Determination of Parameters for Biochar Production from Biomass Waste using Rocking Kiln - Fluidized Bed System
}

\author{
Isa MACM, Sopian. K, Mat. M, Razali H \\ Solar Energy Research Institute (SERI), \\ National Universiti of Malaysia (UKM), \\ Bangi, 43000 Kajang, Selangor, Malaysia
}

\begin{abstract}
Biomass waste is one of the sources for renewable energy. Biomass energy can be produced from combustion technology, anaerobic digestion and pyrolysis. Combustion technologies are such as rotary kiln, fluidized bed, rocking kiln, bed grate furnace, combustor and others. Biomass was converted to bio char using the developed Rocking KilnFluidized Bed (RK-FB) system. RK-FB is a combination technology of rotary kiln, fluidized bed and rocking kiln for combustion. The objective of this work is to measure the optimum parameters to produce the bio char using the RK-FB. In this work, cold run and hot run were conducted to obtain combustion parameters. From this study, parameters obtained from cold run methods were total air for fluidization, rocking speed and residence time while the hot run method obtained parameters of the suitable temperature, the angle of the system, residence time, total air for fluidization, rocking speed, reduction of weight sample and Calorific value of the bio char produced. The samples used in this research were biomass waste from palm oil kernel shells. From the study, the suitable parameter for this new system to work efficiently were temperature $680^{\circ} \mathrm{C}-7200 \mathrm{C}$, flow rate at $200-300 \mathrm{l} / \mathrm{m}$, angle of the rotary kiln at $7^{\circ}$, residence time at $20-25$ minutes and weight reduction of palm oil kernel shells at $70 \%$. The study also found that charcoal or bio char have calorific value, $33 \mathrm{MJ} / \mathrm{Kg}$. It is concluded that the parameters used in this work are suitable the Rocking Kiln - Fluidized Bed for production of bio char from biomass waste.
\end{abstract}

Keywords-Biomass waste; Incineration; Municipal Solid Waste (MSW); commissioning.

\section{INTRODUCTION}

Biomass energy sources are produced from materials that are derived from plants where the sources of these plants coming from either land or sea. Biomass includes all the plants specifically for energy resources or waste products from various woods, plants and municipal waste.

The biggest biomass source in Malaysia comes from oil palm industries. According to (Zuhaira et al., 2018) the oil palm industry is one of the main industries in Malaysia that contributes to the country's gross domestic product (GDP). Malaysia had approximately 4.75 million hectares of palm oil under cultivation which covers about $60 \%$ of the country's agricultural area (Shafie et al., 2012). Malaysia is the second world`s largest supplier of palm oil after Indonesia (Malaysia Palm Oil Sector, 2012) and has supplied $30 \%$ of the world demand on palm oil.
Since Malaysia is the largest production of palm oil, the industry generated vast quantities of palm biomass, mainly from milling and crushing palm oil. According to the Malaysian Palm Oil Industry report (Malaysian Palm Oil Industry, 2014), the types and amount of these biomass generated in 2014 are shown in Table (1).

TABLE 1: PALM OIL BIOMASS GENERATED IN YEAR 2014

\begin{tabular}{|c|c|c|c|}
\hline Biomass & $\begin{array}{c}\text { Quantity } \\
\text { (Million } \\
\text { Tonnes) }\end{array}$ & $\begin{array}{c}\text { Calorific Value } \\
\text { KJ/kg }\end{array}$ & $\begin{array}{c}\text { Moisture } \\
\text { Content } \\
\mathbf{\%}\end{array}$ \\
\hline Shell & 5.2 & 20108 & 12 \\
\hline Fiber & 7.69 & 19068 & 37 \\
\hline
\end{tabular}

Most biomass can be used as combustion fuels. In the normal practice, the kernel shell and fiber used as main fuels for main sources of energy in palm oil mills. The fuels are burn in the boiler to produce steam for electricity generation for use in the milling process (Nasrin et al., 2008).

Biomass energy production from biomass waste can be from combustion technology, anaerobic digestion and pyrolysis. Combustion technology involves rotary kiln, fluidized bed, rocking kiln, bed grates furnace, combustor and others. Rotary kiln technology includes rotation method and the residence time. The residence time depends on the length and diameter of the rotary kiln and the total stoichiometric air given to the system. Fluidized bed is another technology in combustion while the method uses air and sand. The total air located at bottom of fluidized bed system is one factor to contribute the suitable fluidization in the system.

In this work, the determination of combustion parameters is essential in obtaining the desired bio char. Hence, the objective of this research is to study the performance parameters of the Rocking Kiln - Fluidized Bed (RK - FB) system. The parameters involve in the study include the temperature, the angle of the system, residence time, total air for fluidization, rocking speed and reduction of weight sample. 


\section{MATERIALS AND METHODS}

\section{A. Characterization of the Palm Kernel Shell}

The palm kernel shells were obtained from the oil palm processing plant of Seri Ulu Langat Palm Oil Mill Sdn. Bhd, Dengkil, Selangor. Palm kernel shell characterization conducted using proximate and ultimate analysis. Proximate analysis, determine the energy, humidity, volatile matter, ash and fixed carbon found in biomass raw materials (palm shells) using the standard method described in ASTM-84 (American Society for Testing Materials- 84) while the ultimate analysis determine the content of carbon, hydrogen, oxygen, nitrogen, sulfur and ash according to weight percentage basis.

\section{B. Experimental Rig for Biochar Production}

The lab scale Rocking Kiln - Fluidized Bed was designed with the capacity up to $500 \mathrm{gram} / \mathrm{hr}$. The lab scale RK-FB was developed at Malaysian Nuclear Agency and National University of Malaysia to produce bio char from palm kernel shell. The lab scale Rocking Kiln - Fluidized Bed consists of combination of the three components; the rocking kiln, rocking drive system and fluidized bed. The length of rocking kiln chamber is $900 \mathrm{~mm}$ and the internal diameter is $160 \mathrm{~mm}$. Air was blown through the small holes with $4 \mathrm{~mm}$ in diameters and located below the rotary kiln bed which cause it to become fluidized and the fluidized bed. The Rocking rate ranged from 2 to 5 seconds using pneumatic system. In the combustion process for RK-FB cold and hot run procedure were implemented.

The heating rate was controlled by controlling the amount of current LPG and oxygen passing through the burner. The temperature inside the kiln was $700^{\circ} \mathrm{C}$ and the temperature of the external or skin temperature was $160^{\circ} \mathrm{C}$. The residence time and the heating rate were recorded.

There are primary chamber, combustion chamber and secondary chamber as shown in RK-FB drawing in Figure (1). The primary chamber section consists of LPG burners and biomass residues inlet. The chamber combustion part is the place where combustion took place. In combustion chamber, there are fine holes for fluidization and rocking of the system. The secondary chamber is the separation of the flue gas and collection of the product.

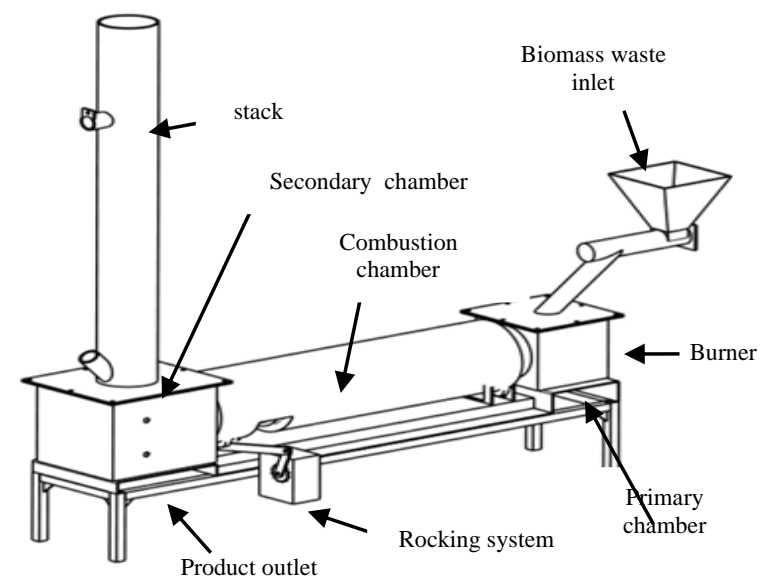

FIGUREURE 1: Schematic Diagram for RK-FB

\section{Cold Run and Hot Run Process}

The cold run and hot run processes with biomass waste were conducted in this work. The purposes of the experiments conducted in the two procedures were to study the efficiency of the rotary kiln and to gain the initial data during the cold run process and the true data during combustion or hot run process.

Cold run process was conducted using air. Rocking method was implemented during the cold run process to obtain data on the total air that was needed and the rocking velocity to move the waste starting from the loading until the unloading at the combustion chamber.

Hot run process was conducted to obtain data for combustion process such as the temperature, residence time, rocking, flow rate needed to become fluidized, product quality and yield of the product. This system is operated by turning the burner so that the temperature inside the burner chamber reaches $700^{\circ} \mathrm{C}$, after which the biomass residue of the palm oil shell will be measured. The burner then will be switched off, and the flow of air will be discharged to the combustion chamber. The rocking system is turned on while the palm kernel shell burnt and the carbonization process took place to convert to bio char. The bio char products were released in the secondary chamber.

\section{RESULTS AND DISCUSSIONS}

\section{A. The proximate analysis and ultimate analysis of palm kernel shell}

The palm kernel shells used in this experiment were taken from oil palm processing plant of Seri Ulu Langat Palm Oil Mill Sdn. Bhd, Dengkil, Selangor. Table (2) tabulated the proximate and ultimate analysis of palm kernel shell. It is observed that the volatile content is high $74.9 \%$. This might contribute to the carbonization effect and the yield of the bio char produced.

The carbon content as shown in Table (2) is high $48.9 \%$, compared to the another study done by (Nor Afzanizam, 2015). From the literature (Nor Afzanizam,2015), the characteristic of the palm oil kernel shell were volatile matter $71.1 \%$, fixed carbon is $18.8 \%$ and ash $4.7 \%$. Table (2) shows that there are variations of the values from the raw material which may be due to factors on the quality of the trees and storage (Ghani et al., 2010).

TABLE 2: THE PROXIMATE AND ULTIMATE ANALYSIS OF THE PALM KERNEL SHELL (Isa et.al., 2018)

\begin{tabular}{|l|c|c|c|}
\hline \multicolumn{4}{|c|}{ Palm Kernel Shell } \\
\hline & This Work & $\begin{array}{c}\text { Nor Afzanizam, } \\
\mathbf{2 0 1 5}\end{array}$ & $\begin{array}{c}\text { Raja Razuan, } \\
\mathbf{2 0 1 1}\end{array}$ \\
\hline & \multicolumn{3}{|c|}{ Proximate Analysis (\%) } \\
\hline Volatiles & 74.9 & 71.1 & 73.7 \\
Fixed & 21.5 & 18.8 & 18.4 \\
Carbon & & 4.7 & \\
Ash Content & 2.1 & 5.4 & 2.2 \\
Moisture & 1.1 & 48.1 & 53.8 \\
\hline \multicolumn{4}{|c|}{ Ultimate Analysis (\%) } \\
\hline Carbon & 48.9 & 6.4 & 7.2 \\
Hydrogen & 5.9 & 1.3 & 0.0 \\
Nitrogen & 0.6 & 0.1 & 0.5 \\
Sulphur & 0.2 & 34.1 & 36.3 \\
Oxygen & 41.4 & \multicolumn{2}{l}{} \\
\hline
\end{tabular}




\section{B. Production of Bio Char}

Cold run and hot run processes were conducted to produce bio char in the Rocking kiln-Fluidized bed system. From the results, it was found that the suitable fluidized is $200-300$ 1/minute and 25 minutes of residence time was needed for the waste to complete the cycle.

The results also showed that combination of rotary kiln, rocking and fluidized bed produced a system that is able to move the biomass waste. The rocking method that was implemented in the system was to ensure that the waste would mix with the air during combustion. The rotary kiln must be rotated at an angle of $7^{\circ}$. The success of fluidized method depends on the total holes located at the bottom part of the rotary kiln. As a result, a large surface area will be produced and this will speed up the waste combustion process.

Hot run or combustion process is another step after obtaining the initial data results from the cold run test. In the hot run method, the operating temperature of the kiln was in range of $680^{\circ} \mathrm{C}-720^{\circ} \mathrm{C}$, which is the normal temperature of the kiln. At this temperature, the combustion of waste took place and was supported by rocking and fluidized to ensure that the combustion process is even. Set-up experiment for the hot run method is shown in Figure (2).

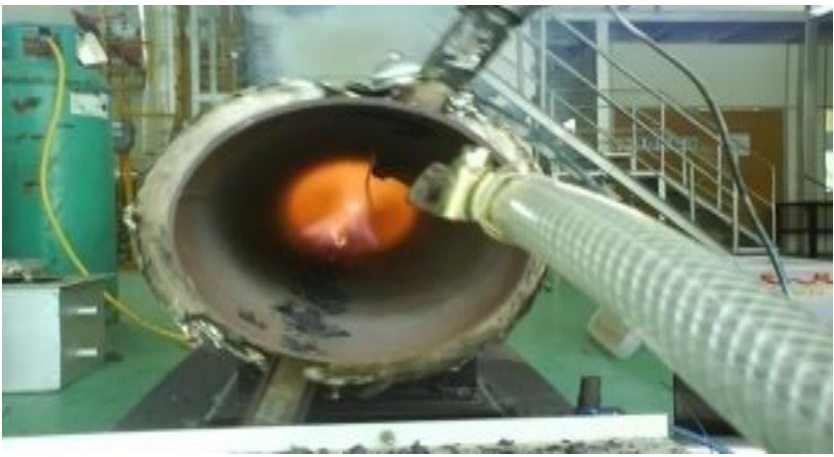

FIGUREURE 2: Combustion of biomass waste in the Rocking Kiln Fluidized Bed

The product produced from rocking Kiln-Fluidized Bed or yield is defined as the percentage of the weight of the final product of carbonization from the initial material weight. Note that the yield does not include the ash content derived from the initial material, which is not removed by any treatment simulating of producing bio char.

The proximate and ultimate analyses of products produced from experimental results are listed in Table (3). The result of the product at temperature $680^{\circ} \mathrm{C}-720^{\circ} \mathrm{C}$ is about $30-35 \%$ yield and carbon content is about $67.01 \%$. The yield shows a decrease with an increase in temperature (Norfadhilah et al., 2019). This agreed with the work of (Abechi, 2013), lower yield is expected at higher temperature as more volatiles are removed. The rate of decrease is faster in the temperature range more than $400^{\circ} \mathrm{C}$, which is characteristic of the behavior of the carbonization process. Produced the yield of carbon char about $29 \%$ at $600^{\circ} \mathrm{C}$ using the same raw material (Yang et al., 2006). (Stanislaw et al., 2018), used pyrolysis process found that the carbon content increases from $50 \%$ to $63 \%$ with increases in process temperature from $300^{\circ} \mathrm{C}$ to $400^{\circ} \mathrm{C}$. When the temperature increased from $200-500^{\circ} \mathrm{C}$, the carbon char yield decreases from $99.3 \%$ to $26.8 \%$ in wheat straw carbon char and $98 \%$ to $35.8 \%$ in pig manure carbon char (Liu et al., 2015). Carbon char produced from eucalyptus tree bark was $68 \%$ and corncob was 33\% (Kanouo Djousse et al., 2017). From pyrolysis process conducted by Stanislaw (2018), total mass produced depending on the temperature with $50.07 \%$ mass yield of carbon char at $400^{\circ} \mathrm{C}$ and $88.57 \%$ mass yield of carbon char at $300^{\circ} \mathrm{C}$.

TABLE 3: THE PROXIMATE AND ULTIMATE ANALYSIS OF THE PRODUCT

\begin{tabular}{|lr|lr|c|}
\hline Proximate Analysis (\%) & \multicolumn{2}{|c|}{$\begin{array}{c}\text { Ultimate Analysis } \\
(\%)\end{array}$} & $\begin{array}{c}\text { Calorific Value } \\
\text { (MJ/KG) }\end{array}$ \\
\hline & & Carbon & 67.01 & \\
Volatiles & 21.53 & Hydrogen & 3.41 & \\
Fixed Carbon & 75.90 & Nitrogen & 0.74 & 33 \\
Ash Content & 2.25 & Sulphur & 0.20 & \\
Moisture & 1.2 & Oxygen & 12.59 & \\
& & Ash & 2.00 & \\
\hline
\end{tabular}

Table (3) shows the elemental composition found in the ultimate analysis. The elemental compositions were Carbon $(\mathrm{C})$, hydrogen $(\mathrm{H})$ and oxygen $(\mathrm{O})$ which are the main components in the analysis. This results agreed with the work of (Ghani et al., 2010). During carbonization $\mathrm{C}$ and $\mathrm{H}$ are oxidized to form $\mathrm{CO}_{2}$ and $\mathrm{H}_{2} \mathrm{O}$. The content of $\mathrm{C}$ and $\mathrm{H}$ contributes to the positive calorific value (Ghani et al., 2010). The calorific value after carbonization is much higher that is $33 \mathrm{MJ} / \mathrm{kg}$ as compared to the calorific value of the raw palm kernel shell without underwent carbonization process that is only $24 \mathrm{MJ} / \mathrm{KG}$. According to (Ghani et al., 2010), the high calorific value is due to the high carbon content in the sample.

\section{Effect of the air fluidization for the production of Bio Char}

The temperatures were set at $680-720^{\circ} \mathrm{C}$ at angle 7 degrees. From the experiments, the total air flow rate in the range of $50-850 \mathrm{l} / \mathrm{m}$. From Figure (3) the air flow rate in the combustion chamber was $50 \mathrm{l} / \mathrm{m}$. This resulted in $94 \%$ burnt of palm kernel shell with residence time of $60 \mathrm{~min}$. However, the amount of bio char produced was $4 \%$ and the quality of the bio char was $32 \mathrm{MJ} / \mathrm{kg}$. At $800 \mathrm{l} / \mathrm{m}$ flow rate the quality of the charcoal produced was low and approaching the quality of original palm kernel shell with low residence time. This shows that with high flow rate the palm kernel shell was not able carbonized.

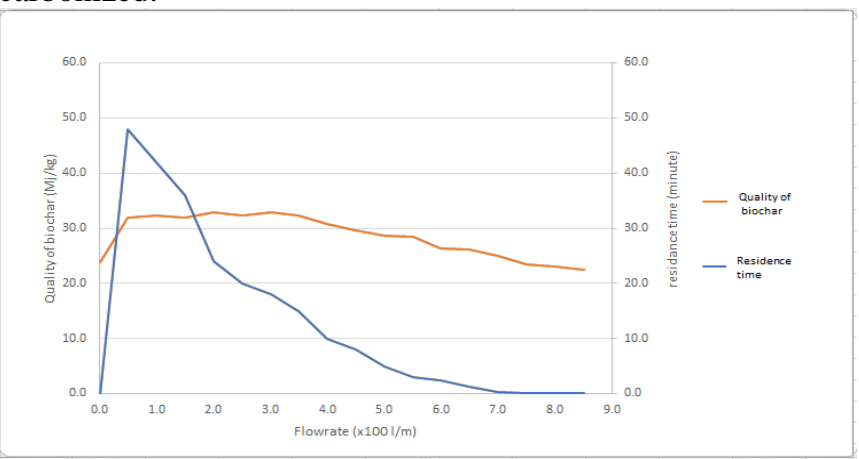

FIGURE 3. EFFECT OF THE AIR FLUIDIZATION FOR THE PRODUCTION OF BIO CHAR 
Figure (3) showed the optimum air flow rate to produce quality and quantity bio char. At air flow rate of $2001 / \mathrm{m}$, residence time $20-25 \mathrm{~min}$, amount of bio char produced were $30-35 \%$ with $33 \mathrm{MJ} / \mathrm{kg}$. This shows that only $30-35 \%$ of bio char produced from $100 \%$ raw palm kernel shell. According to (V. Idakiev et al., 2013), the residence time is influenced by the air flow that enter the chamber. In his study, the materials dispersed in continuous operation while the residence time decreased as the flow rate increased.

The charcoal production from the combustion is affected by the amount of air flow rate. The air flow rate also affects the residence time of the raw material in the combustion chamber until the product is released.

\section{Effect of the Rocking Angle}

Figure (4) shows the effect of the rocking angle of the system. The angle effects the quality of the product and the produced yield. In this work, the flow rate was at $2001 / \mathrm{m}$ and $300 \mathrm{l} / \mathrm{m}$ with temperature at $680^{\circ} \mathrm{C}-720^{\circ} \mathrm{C}$. At flow rate 200 $1 / \mathrm{m}$ and $300 \mathrm{l} / \mathrm{m}$ with 2 degree rocking angle, the yield was $15 \%$ and the quality bio char produced was $30 \mathrm{MJ} / \mathrm{Kg}$. This is due to only $15 \%$ was produced when $100 \%$ biomass waste inserted in the RK-FB combustion chamber. This is due to small angle and long residence time 55 minutes cause the bio char burnt stated that the angle of the rotary kiln effect the bio char produced. Further increased in the angle will cause inadequate residence time for feed to complete the combustion (Gajendra Kumar et al., 2014).

From Figure (4) at angle 7 degree, highest production bio char at $30 \%$ with high quality at $33 \mathrm{MJ} / \mathrm{kg}$ and residence time at 20-25 minutes. With the same flow rate, a $200 \mathrm{l} / \mathrm{m}$ and 300 $1 / \mathrm{m}$, the difference is only $5 \%$. Thus the optimum angle was at 7 degree

At angle 10 degree, the yield was $35 \%$, however, the quality of the product decreased at $28 \mathrm{MJ} / \mathrm{kg}$. When the angle increased, the carbonization happened in shorter time and most of the kernel shells did not carbonized efficiently.

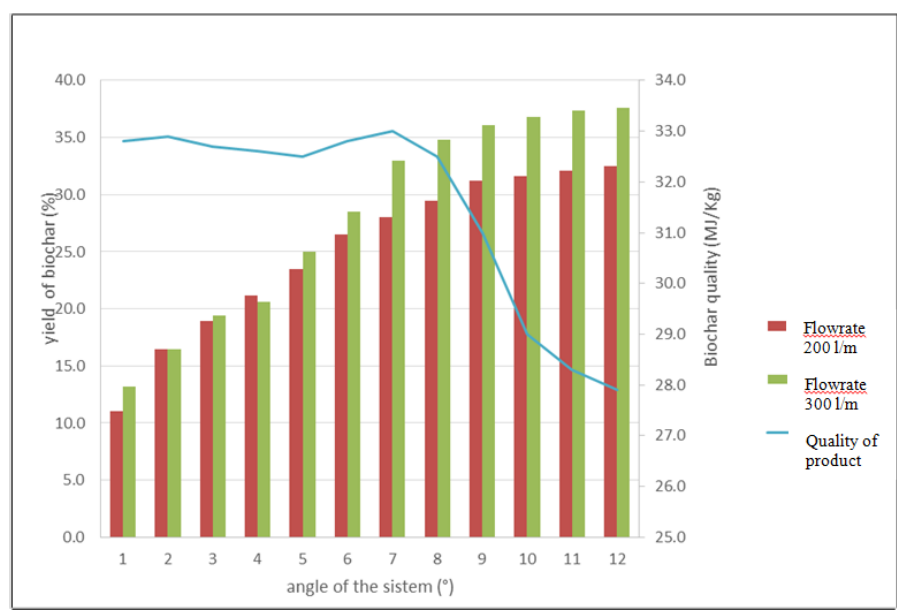

FIGURE 4. EFFECT OF THE ROCKING ANGLE IN THE PRODUCT PRODUCED

\section{E. New Parameters for RK-FB}

In this study, a new concept of laboratory lab scale system was developed which combines the three components which are the rotary kiln, rocking and fluidized bed made the system work efficiently. According to the literature (National Guidelines for Hazardous Waste Incineration Facilities, 1992) the combustion temperatures vary according to the characteristics of the waste material but in general the range is between $810^{\circ} \mathrm{C}-1650^{\circ} \mathrm{C}$. However, the operating temperature for Rocking Kiln-Fluidized Bed which is used in this research is much lower that is starting from $680^{\circ} \mathrm{C}-$ $720^{\circ} \mathrm{C}$. The European Von Roll organization which produces a rocking kiln which is the same as a rotary kiln with rotation at 45 degree from centre in each direction also has the operating temperature from $600^{\circ} \mathrm{C}-1300^{\circ} \mathrm{C}$ which is slightly higher than the operating temperature for RK-FB produced and (National Guidelines for Hazardous Waste Incineration Facilities., 1992). The new parameters used in this research are tabulated in Table (4).

TABLE 4: NEW PARAMETERS USED IN THIS WORK

\begin{tabular}{|l|l|}
\hline Parameters & Units \\
\hline Temperature & $680^{\circ} \mathrm{C}-720^{\circ} \mathrm{C}$ \\
\hline Air Flowrate & $200-3001 / \mathrm{m}$ \\
\hline Rocking displacement & $90^{\circ}$ \\
\hline Angle of the rotary kiln & 7 degree \\
\hline Residence time & $20-25$ minutes \\
\hline Weight reduction of palm oil kernel shells & $70 \%$ \\
\hline
\end{tabular}

\section{CONCLUSION}

From the experimental results, cold run and hot run process can be used to obtain combustion parameters. The optimum parameters obtained from cold run process were total air for fluidization at $200-300 \mathrm{l} / \mathrm{min}$, the rocking angle was at 7 degree and residence time at 20-25 minutes while the hot run process obtained the suitable parameter for this new system to work efficiently were temperature $680^{\circ} \mathrm{C}-720^{\circ} \mathrm{C}$, flow rate at 200-300 1/m, angle of the rotary kiln at 7 degree and weight reduction of palm oil kernel shells at $70 \%$. This system is capable to process biomass waste with complete combustion to produce energy and carbonization for production of charcoal. The produced bio char have calorific value, $33 \mathrm{MJ} / \mathrm{Kg}$.

\section{ACKNOWLEDGMENT}

The authors wish to thank Malaysia Nuclear Agency and Solar Energy Research Institute (SERI), National University of Malaysia (UKM) for the usage of the facilities, support and encouragement in conducting this research.

\section{REFERENCES}

[1] Abeschi, "Preparation and Characteristic of Activated Carbon From Palm Kernel Shell By Chemical Activation," Research Journal of Chemical Sciences, Vol. 3(7), 54-61,2013.

[2] CCME, "National Guidelines for Hazardous Waste Incineration Facilities", Volume 1, Ontario,1992

[3] Djousse Kanouo, B. M., Allaire, S. E. and Munson, A. D (2017) Quality of bio chars made from eucalyptus tree bark and corncob 
using a pilot scale retort kiln. Waste and biomass valorization, 9(6), 899-909

[4] EPA, "Hazardous Waste Incineration, Handbook, Permit Writer Guide to Test Burn Data, 1986

[5] Evbuomwan, B.O, Agbed A.M, Atuka M.M. A, "Comparative Study of ThePhysico-Chemical Properties of Activated Carbon From Palm Oil Waste," International Journal of Science and Engineering Investigations, Vol.2, Issues 19, 2013.

[6] Gajendra Kumar Gaurav,Shabina Khanam, "2 D Model of Sponge Iron Rotary Kiln Developed Using CFD," Conference Proceeding (EEECOS 2014) ISSN: 2321-9939, 2014.

[7] Liu, W.J, Jaing, H and Yu, H.Q, "Development of bio char based functional materials toward a sustainable platform carbon material," American chemical society, Chem.Rev.115(2), 12251-12285, 2015.

[8] Mohamad Azman Che Mat Isa, Kamaruzzaman Sopian, Sohif Mat and Halim Razali, "Efficiency of the Rocking Kiln - Fluidised Bed for Charcoal Production,” Jurnal Kejuruteraan SI 1(7), 81-86, 2018.

[9] MPOB. Malaysian Oil Palm Industry: Overview of the Malaysian Oil Palm Industry, "Retrieved from MPOB retievedwebsite:http://bepi.mpob.gov.my/images/overview/Overvie w_of_Industry_2012.pdf, 2014.

[10] Norfadhilah Hamzah, Koji Tokima, Kunio Yoshikawa, "Solid Fue from Oil Palm Biomass residues and Municipal Solid Waste by Hydrothermal Treatment for Electrical Power Generation in Malaysia: A Review," Sustainability 1060; doi: 10.303390/su/1041060, 2019.

[11] Nasrin, A.B.,MA A.N., RohayaM.H, "Oil Palm Biomass as Potential Substitution Raw material for commercial Briquettes Production," American Journal of applied Sciences: 179-183, 2008.
[12] Nor AfzanizamSamiran, MohamadNazriMohdJaafar, "A Review of Palm Oil Biomass as a Feedstock for Syngas Fuel Technology," JurnalTeknologi, 2014.

[13] Raja Razuan Raja Deris, "Combustion and Slow Pyrolisis of Oil Palm Stones and Palm Kernel Cake,” PhD Thesis, The University ofSheffield, 2011.

[14] Shafie S.M., Mahlia T M.i, Masjuki H.H, “A Review On Electricity Generation On Biomass Residue In Malaysia,” Journal of Elsevier, 2012

[15] Stanislaw S.,Anna P., Monika Z, "A New Approach for evaluating bio char quality from Mallow Biomass Thermal Processing," Journa of Cleaner Production, 356-364, 2018.

[16] Tihay V., Gillard, "Pyrolysis gases released during the thermal decomposition of three Mediterranean species," Journal of Analytical and Applied Pyrolysis, Vol.88, no.2, pp.168-174, 2010

[17] V.Idakiev, L. Morl, "Study of Residence Time of Disperse Materials in Contionously Operating Fluidized Bed Apparatus," Journal of Chemical Technology and Metallurgy, 48,5,415-456, 2013.

[18] Wan Ab Karim GhaniW.A., Abdullah M.S.K, "Physical and ThermoChemical Characteristic of Malaysia Biomass Ashes," Journal The Institutes of Engineers Malaysia,Vol.71, no.3, 2010.

[19] Xiong Z.H., Chang J., Wu, C.Z., Chen Y., Zhu J.X, "An experimental study on biomass air-steam gasification in a fluidized bed," Bio Resources.Technol, 95-101, 2004.

[20] Zuhaira M Z., Fazida H H., Thinaj r., Aqilah B H, “A rapid and Non-Destructive Tehnique in Determining the Ripeness of Oil Palm Fresh Fruit Bunch (FFB),” Journal Kejuruteraan ,93-101, 2018 